\title{
Socio-Political Coordinates of Early-Modern Mechanics: A Preliminary Discussion
}

\author{
Pietro Daniel Omodeo \\ Ca' Foscari University of Venice \\ ERC Endeavor EarlyModernCosmology (GA 725883)
}

\begin{abstract}
:
How does a cultural-political understanding of science integrate socio-economic treatments? How can a subjectivity aware historiography avoid the pitfall of post-modern relativism? The history of mechanics is a paradigmatic field to answer these questions and, in fact, it has always been at the center of much political-epistemological skirmish. This chapter first recounts the main motives and features of early twentieth-century social accounts of science. Further, it deals with the issue of how the need of a non-reductionist treatment of intellectual history (neither economicist nor monocausal) calls for an integration of the economic context and the political element for a more appropriate understanding of scientific development.
\end{abstract}

\section{Keywords:}

- Political epistemology

- Science and cultural hegemony

- Socio-political history of mechanics

- Marxist historiography of science

- Boris Hessen

- Henryk Grossman

- Edgar Zilsel

- Antonio Gramsci

In the history of science of the last century, in an age of irreconcilable dichotomies mirroring the geo-political divide between Capitalism and Real Socialism, Marxist historians undertook a socio-economic investigation of science fostering an approach that came to be labeled as "externalist." On the opposite front, that of the so-called "internalists," an idealistic conception of science prevailed, one that was seen as politically correct. Its rejection of everything "material" was meant to immunize the discipline against socialist contamination. ${ }^{2}$ By the Nineties, the turn away from modernist concerns about all-encompassing interpretations generated a plethora of post-modern narratives in which historians' subjectivity came to the foreground - often at the expense of careful source analysis and theoretical clarity. ${ }^{3}$ Broadly speaking, the new mainstream shows a culturalist bias whose ostensible (and celebrated)

\footnotetext{
${ }^{1}$ See Porter (1990) and Young (1990). Also see Long (2011).

2 See Omodeo (2016b).

${ }^{3}$ I discuss this issue with Roger Cooter in Omodeo (2015).
} 
advantage is to substitute the opposition between socio-economic accounts and theoretical/technical investigations for a more circumscribed treatment of local environments that takes into account (and often overemphasizes) the actors' perspectives. ${ }^{4}$ To be sure, this outlook (often micro-historical, ethnological/anthropological) has served to remedy rough anachronisms and generalization, and the post-modernist emphasis on rhetoric and narrativity gave a worthy caution against the preposterous assumption/prescription of objectivity and detachment on the historians' part. However, it has also produced increasing historical fragmentation and theoretical vagueness about epistemology and the foundations of science. The postmodern-cum-culturalist conjuncture raises two interrelated questions: How does a cultural understanding of science integrate earlier economic and technical treatments? Furthermore, how can a subjectivity aware historiography avoid the pitfall of relativism, well captured by the epistemological slogan "anything goes"? The legacy of earlier paradigms has remained quite obscure. In particular, the extent of their validity has not been fully reflected.

It seems appropriate to deal with these issues beginning with a historical/historiographical reflection on early modern mechanics. In fact, this field has been at the center of much ideological skirmish since the 1930s. The most notable contrast was that which opposed Edgar Zilsel's economic explanation of the rise of modern science to Alexandre Koyré's defense of its purely speculative origins (Lefèvre 2001). In the following discussion I will recount the main motives and features of early twentieth-century social accounts of science. Further, I will point to how the need of a non-reductionist (neither economicist nor monocausal) treatment of intellectual history calls for an integration of the economic context and the political element for a more appropriate understanding of scientific development. In order to articulate my proposal, I will eventually delve into a case study in Chapter 7 of this volume: a discussion of the sociopolitical coordinates of a typical Renaissance scholar in mechanics of the generation between Girolamo Cardano and Galileo Galilei, Giovanni Battista Benedetti.

\section{The Marxist Paradigm: Mechanics between Basis and $\ddot{U} b e r b a u$}

One of the most quoted and controversial passages of Karl Marx's œuvre, his preface to Zur Kritik der politischen Ökonomie (A Contribution to the Critique of Political Economy) (1859), offers a significant sketch of his conception of culture in relation to history and society. In this text he introduces the distinction between economic structure (Struktur or reale Basis) and juridical and political superstructures (Überbau), which correspond to determinate historical forms of consciousness. He famously asserted that: "It is not the consciousness of men that determines their existence, but their social existence that determines their consciousness." (Marx 1987, 263) Thus he affirmed the dependence of consciousness on sociohistorical settings. Similarly, Marx saw the ideological formations - juridical, political, religious, artistic, and philosophical - as rooted in the terrain of the economic conditions of production. It should be remarked that he did not enlist science among the ideologische Formen. Rather, he ascribed to Naturwissenschaft a

\footnotetext{
4 The reference work that is mostly mentioned as a watershed in the history of science is Schaffer and Shapin (1985). See their "Introduction to the 2011 Edition: Up for Air: Leviathan and the Air-Pump a Generation On," in Leviathan and the Air-Pump: Hobbes, Boyle and Experimental Life (2011).
} 
special status. ${ }^{5}$ By arguing that the evolution of the conditions of production (Produktionsbedingungen) can be investigated with the accuracy of the natural sciences, he implied that the latter have a degree of objectivity that is superior to that of the other disciplines. $\mathrm{He}$ did not discredit the aforementioned intellectual (ideological) realms, as they are the means through which people become aware of their positioning in society. And he compared science, in this case economy, to Dante's descent to the hell in the third Canto of the Inferno...

\section{Qui si convien lasciare ogni sospetto \\ Ogni viltà convien che qui sia morta. ${ }^{6}$}

For Marxist historians of science reflecting on these pages, science constituted an epistemological puzzle: Does it belong to the structural sphere or to the superstructural? On the one hand, according to the preface to the Kritik der politischen Ökonomie, natural science appears to escape cultural determination; this would make the analysis of its relationship to philosophy, art, and religion as well as to the political context superfluous. On the other hand, science cannot be reduced to economy tout-court. Rather, it occupies an intermediate epistemological position between Basis and Überbau, as its history clearly shows (see Table 1). From the Thirties to the Fifties, Marxist inquiries in the history of science, from Boris Hessen to John Bernal, Henryk Grossman and Zilsel, especially stressed the dependency of science on economics - and this inquiry was made more difficult by controversies over the relation between economics and technology. Moreover, within the Marxist tradition, debates about the interrelation of structure and superstructure, politics and consciousness, and science and ideology determined fluctuations in the understandings of science. ${ }^{7}$ Later social accounts, often departing from Marxism, explored the connection of science with cultural realms such as religion (Merton's Weberian school), philosophy (e.g. Paolo Rossi), art (e.g. Pamela Smith) and politics (e.g. Mario Biagioli).

I will begin my assessment with the earlier trend pointing out the economic roots of science. Boris Hessen's "The Social and Economic Roots of Newton's Principia" - a classic of Marxist historiography of science, as Gideon Freudenthal and Peter McLaughlin have called it - was a talk delivered at the second International Congress of the History of Science and Technology in London in $1931 .^{8}$ Hessen was one of the Soviet delegates deputed to present and promote the Marxist way of the history of science. His talk on Newton was one of the most articulated among those delivered by the Soviet delegates, and had a lasting impact on subsequent studies on the Scientific Revolution. The aim of his talk was to reject the semi-mythical treatment of Newton's physics as the product of a lonely genius detached from mundane interests by demonstrating that the Principia was the historical product of a scientific process induced by economy-driven technological advance.

\footnotetext{
5 Cf. Stachel (1994).

${ }^{6}$ Here all misgiving must thy mind reject./ Here cowardice must die and be no more.

${ }^{7}$ On the oscillating assessment of the relationship between structure and superstructure and its relevance in cultural studies, see Hall (1980). The problem of consciousness is typically Lukácsian, whereas that of ideology and science is generally connected to the Frankfurter Schule. See for instance Habermas (1969). More recently, the Foucauldian strand has pointed out the biopolitical dimension of science, which goes beyond the "mental" emphasized by the concept of ideology. For an insightful discussion and case study, see Bruskell-Evans (2015).

${ }^{8}$ Hessen's essay first appeared in Science at the Cross Roads (London: Kniga, 1931), reprinted in 1971 (London: Frank). I will cite from the most recent edition in Freudenthal and McLaughlin. (2009).
} 
In order to set the theoretical stage of his analysis, Hessen began with Marx's preface to the Kritik der Politischen Ökonomie whose treatment of the structure/superstructure distinction he summarized as follows: "The mode of production of material life conditions the social, political and intellectual life process of society." (Freudenthal and McLaughlin 2009, 42, emphasis added) Although he stressed the dependency of the superstructure on the economic basis, in my opinion he left open for debate the question of whether this conditioning had to be seen as monocausal and deterministic or not. By contrast, the leader of the Soviet delegation, Nikolai Bukharin, had a clear-cut opinion on this matter. In his popularizing introduction to Marxist philosophy, The Theory of Historical Materialism: A Popular Manual of Marxist Sociology (1921), he had argued, on a materialist basis, for the naturalization of the laws of social development as dealt with by Marxist sociology (or "historical materialism," according to his understanding of it). He also embraced a strictly deterministic conception of both natural and social processes. He wrote that "in nature and society there is a definite regularity, a fixed natural law. The definition of this natural law is the first task of science. This causality in nature and society is objective." (Bukharin 1934 [1921]) Social developments, according to him, are as predictable as eclipses or the boiling of water (ibid., 51).

Hessen refrained from such a crude naturalization of history. Instead, he reflected on the dynamics of science in relation to economy and technology, on the one hand, and politics, philosophy and religion, on the other. However, according to the assumption of a fundamental dependency of the superstructural upon the structural, Hessen considered the socioeconomic linkage of science to be more fundamental than its cultural embedment. To sum up his model, "economics [...] present $[s]$ demands, which pose technical problems, which generate scientific problems" (Freudenthal and McLaughlin 2009, 4).

The economy of Newton's time was that of the rise of early capitalism, marked by the expansion of merchant capital and manufacture. A new class of entrepreneurs emerged in late medieval and early modern Europe, and their interests were closely linked to the expansion of communication (and transport), industry and war. Hessen detailed the technical problems raised by the expansion of these three areas and the corresponding scientific fields that flourished during the sixteenth and seventeenth centuries in Europe. First, the needs of communication and transport, mainly maritime, required the improvement of vessels, the development of new navigation techniques, especially in the Oceans, and the building of canals and locks. In order to tackle the technical problems of navigation, improved hydrostatics and hydrodynamics were needed as well as astronomical, geographical, mathematical and optical knowledge. Second, the most important realms of industry were mining and war, and the technical problems of these realms could be solved by chemical and mechanical experts of a variety of topics ranging from simple machines to hydro- and aerostatics and the science of materials. Third, the military requirements of a time marked by the introduction of firearms led to the perfection of ballistics and fortification techniques, the study of dynamics and of architecture.

After his overview of the economic, technical and scientific characteristics of Newton's age, Hessen offered a summary of the central problems faced by early modern mechanics. Here the main issues follow: 1. simple machines, inclined planes and statics in general; 2. free fall and projectile trajectories; 3. hydrostatics and aerostatics, atmospheric pressure and the motion of bodies through a medium; and 4. celestial mechanics and the theory of tides. As 
collateral subjects, Hessen mentioned optics and magnetism. Additionally, he produced a list of the scientific protagonists - it comprised Leonardo da Vinci, Cardano, Del Monte, Stevin, Galileo, Tartaglia, Riccioli, Guericke, Pascal, Boyle, Kepler and a few other big names (Hessen in Freudenthal and McLauglin, 52). He also mentioned en passant Agricola, for mining, and Gilbert, for magnetism, a discipline whose economic-technological raison d'être resided in navigation. According to Hessen, Newton brought all of these branches of physics to a theoretical synthesis but this intellectual achievement should not obscure its deep economic and technical roots.

After considering the structure underlying early modern mechanics, Hessen dealt with its superstructure. As he cautioned his listeners, "It would [...] be a gross oversimplification to derive every problem studied by various physicists, and every task they solved, directly from economics and technology. [...] The economic situation is the basis. But the development of theories and the individual work of a scientist are also affected by various superstructures, such as political forms of class struggle and its results, the reflection of these battles in the minds of the participants - in political, juridical, and philosophical theories, religious beliefs and their subsequent development into dogmatic systems." The political context of Newton was that of "reformism" sanctioned by the Glorious Revolution of 1688, that is, a compromise between the interests of the Monarchy and those of the bourgeoisie that had heralded the English Revolution of 1648. According to Hessen, this climate of moderation and settlement (the "class compromise of 1688" as he called it) informed Newton's piety which, in turn, affected the philosophical viewes underlying the Principia. Thus, God and idealistic assumptions entered his conception of nature. Although radical materialistic and mechanistic views were available in his time (such as those by Richard Overton, Thomas Hobbes, René Descartes and John Toland), Newton refrained himself from these excesses. He assumed that a teleological principle of divine origin preserves the universe and its order; he considered motion to be a mode superimposed on essentially inert matter and viewed space as a sensorium Dei separable from matter. To sum up Hessen's considerations on superstructures and science, the cultural environment Newton operated within - in one word, his "ideology" - only accounted for the perceived shortcomings of his system, essentially its distance from an accomplished material and physical (as well as evolutionary) account of nature like the one that would be produced by Laplace in the time of the French Revolution. ${ }^{9}$

It should be remarked that Hessen did not posit a unidirectional dependency of science on technology. Rather, he pointed out a possible feedback mechanism, that is, a dialectical reinforcement of technology through science and vice versa: "The immense development of technology was a powerful stimulus to the development of science, and the rapidly developing science in turn fertilized the new technology" (Hessen 2009, 84). However, he did not go so far as to expand this idea on a more general explanatory level: He did not explicitly admit a similar dialectical loop between technology and economy and, even less so, between economy and politics, or politics and philosophy. In other words, his conception of the relation of structure and superstructure did not overtly challenge economic reductionism. However, he acknowledged that science is affected by the cultural element alongside the economic-technological. As he did not survive the Stalinist purges, he could never develop

\footnotetext{
${ }^{9} \mathrm{~A}$ similar idea, that ideology only accounts for the shortcomings of science, has been defended by the influential exponent of the French épistémologie historique George Canguilhem (2009).
} 
and circulate the details of his research program. ${ }^{10}$ It was Robert Merton's achievement to develop Hessen's insight by considering in more detail the incidence of technology, on the one hand, and puritan ethics (distinct from theology), on the other, in the natural debates of Newton's time in his classic of Weberian sociology of science, Science, Technology and Society in Seventeenth Century England (1938). ${ }^{11}$

With the benefit of hindsight some limitations of Hessen's approach become apparent. Although he embraced a view of technology as the product of collective and largely anonymous human activity and, on this basis, discarded Romantic views about scientific genius, he nonetheless focused on the explanation of an individual work through its context and did not put too much emphasis on the collective production of knowledge. Ludwig Fleck's concept of Denkkollektiv, referring to the collective dimension of science, and his emphasis on education as a central moment in the formation of a scientific culture, constitute a valid complement to Hessen's conception. Regrettably, even after the publication of Fleck's Entstehung und Entwicklung einer wissenschaftlichen Tatsache (The Genesis and Development of a Scientific Fact, 1938), the reception of his ideas was arrested by the outbreak of WWII, Fleck's deportation, and the dispersion of the German-speaking community of Mitteleuropean philosophers of science to whom his work was directed. ${ }^{12}$ Eventually, Thomas Kuhn's The Structure of Scientific Revolutions (1962) disseminated and popularized Fleck's collectivist view of science, style of thought, and pedagogy by introducing categories such as "paradigm" and "normal science." Hessen did not deal with the epistemological problem of shared knowledge and paid but little attention to its collective character, although he incidentally referred to seventeenth-century academies, the Accademia del Cimento and the Royal Society, as new places of scientific experimentation and knowledge production. As for teaching institutions, characterized by the long-lived scholasticism, he saw the early modern universities as a hindrance to the advance of natural and technical knowledge. As I will discuss, Zilsel's position on the role of traditional education in the rise of modern science proved more detailed and comprehensive than that.

In recent years, our understanding of the shared character of theoretical knowledge has been improved through consideration of its long-lasting cognitive models, or "mental models." These have been defined as "instruments for drawing conclusions in the context of given knowledge" which "link present with past experiences by embedding new experiences in a cognitive network of previous experiences." 13 Unlike the platonically conceived scientific concepts investigated by Koyré in his idealistic history of science, ${ }^{14}$ cognitive models bypass the sharp separation between experience and theory by identifying durable conceptual-

\footnotetext{
${ }^{10}$ For the intellectual context of Hessen's work, see Winkler (2013). At his death, Hessen had an anthology of sources of early modern science ready for print. I am very thankful to Rose Luise Winkler and Peter McLaughlin for making it available at: http://www.philosophie.uni-hd.de/md/philsem/personal/hessen_textbook.pdf (accessed September 2, 2016). Cf. Winkler (2007).

${ }^{11}$ Merton (1938). Merton openly acknowledged his intellectual debt toward Hessen but limited this to the issue of technology. See 501-502.

12 Cf. Schäfer (2012). On the split of rationality, Spaltung der Rationalität, resulting from the violent interruption of a virtuous synergy of natural science and philosophy from the mid-eighteenth century to the 1930s, see Engler and Renn (2010).

13 See Renn and Damerow (2007). See Chapter 1 of this volume.

${ }^{14}$ Cf. Koyré (1943). This essay can be seen as the author's manifesto of a disembodied history of science, as developed in his major works. The most important for the history of mechanics are Études galiléennes (Paris, 1939) and Newtonian Studies (Cambridge, Mass., 1965). In "Galileo Engineer” Lefèvre criticized Koyré's speculative attitude and his neglect of the social context of early mechanics.
} 
experiential instruments, for instance the basic model of motion-implies-force that was crucial to a millenary tradition of Aristotelian and post-Aristotelian dynamics. ${ }^{15}$ Attention to such elementary components of scientific thought permits us to bring into focus deep theoretical continuities in spite of apparent discontinuity and vice versa. For instance, one can mention the enduring presence and transformation of scholastic concepts in the physics of eminently anti-Scholastic scientists such as Galileo or Descartes (Damerow et al. 2004). Moreover, the inner constraints of shared models account for concomitant discoveries in the history of science, for instance the convergence of the methods and results in scholars working independently from each other, as in the case of Galileo and Thomas Harriot's dynamics (Schemmel 2008). In the light of shared knowledge, issues of priority become less relevant. In the case of planetary theory after Copernicus, it can be argued that the acceptance of his epicyclical models and parameters combined with the rejection of terrestrial motion and eccentricity necessarily led to the independent "discovery" of the geo-heliocentric system by several astronomers agreeing on common premises. Consideration of such theoretical constraints sheds a very different light on the past polemics over priority of discovery. In this case, the heated and well-known polemics over the paternity of geo-heliocentrism that burst out between the Danish astronomer Tycho Brahe and the Imperial mathematician in Prague, Nicolaus Reimers Ursus, should not obscure the fact that it is possible, even likely, that scholars working on the same research program which rests on the same premises can come to similar solutions to given problems. ${ }^{16}$ This instance also shows that the inquiry into the conceptual dimension and the inner developments of science is not unrelated to its social context. Rather, consideration of shared knowledge offers an additional tool for the comprehension of the dynamics of knowledge at both a social level and a cognitive level.

Shortly after Hessen and independently from him, Henryk Grossman, a Marxist scholar linked to the Frankfurt Institute for Social Research, dealt with questions concerning science and society in the early phases of modernity in Die gesellschaftichen Grundlagen der mechanistischen Philosophie und die Manufaktur (The Social Foundation of Mechanistic Philosophy and Menufacture, Paris, 1935). It was a critical review commissioned by Max Horkheimer, directed against the Marxist historian Franz Borkenau's simplistic treatment of early mechanics. In Der Übergang von feudalen zum bürgerlichen Weltbild (The Transition from the Feudal to the Bourgeois World Picture, Paris, 1934), Borkenau argued that modern mechanics rose from a direct abstraction from the labor conditions of rising capitalism. Grossman reprimanded Borkenau for his lack of historical accuracy, which he saw as particularly due to a literal and rigid application of Marx's periodization, as well as an insufficient understanding of early-capitalist social developments. Most importantly for our present concern, Grossman argued that mechanics originated from reflection on machine technology in the late Middle Ages and the Renaissance. According to a thesis, which is also known as the "HessenGrossman-Thesis," "technology was developed in order to facilitate economic development, and science developed by means of the study of the technology that was being applied or developed" (Freudenthal and McLaughlin 2009, 4).

\footnotetext{
15 Cf. Renn and Damerow (2007).

16 See Omodeo (2014).
} 
Grossman mentioned Da Vinci as the Idealtyp of modern mechanical thought. Moreover, he took Descartes into consideration, alongside Boyle, Galileo and Hobbes, to make the point that, for these early scientists, mechanics was first of all a theory of machines. As Grossman observed, "the machines mentioned by Descartes [...] can be divided into four categories: artillery, clock, water and lifting machines, [they] also represent the most important areas of practical mechanics, by which the basic concepts and laws of theoretical mechanics could be developed. Mechanics was only slowly created by the struggle of human ratio with the empirical material." 17 Hessen, who shared this view, also brought forward the reverse argument: The fields of physics that did not come to the forefront of the discipline in the seventeenth century are those that could not rely on a sufficiently developed technology (e.g. the science of heat, due to rudimentary steam engine technology) (Freudenthal and McLaughlin 2009, 20).

This insight by Hessen and Grossman has proved fruitful in the history of mechanics. In recent years, the study of the interrelation of technology and science has received new impetus. Accurate studies on Renaissance mechanics have deepened the link of this discipline with machine technologies. As has been argued, theoretical knowledge was gained through abstraction from experience and the reflection on "challenging objects" such as balances, turning wheels or projectiles. ${ }^{18}$ Practice-oriented mathematicians like Cardano, Tartaglia, Del Monte, Benedetti, Stevin and Galileo built on craftsmen's experience and based their theories on technological objects from architecture, ballistic and navigation, to mention only the most visible developing fields of the early modern period. Grossman's idea that seventeenth-century "mechanistic philosophy and scientific mechanics derived their basic mechanical concepts from the observation of mechanisms and machines" is still valid (Grossman 2009, 107). Today we can rely on detailed accounts of the interconnection between modern mechanics and machine technology, at the intersection of theoretical and practical activity. Indeed, the Renaissance was a time in which the rediscovery of Archimedes and the pseudo-Aristotelian Mechanical Problems merged with the scholastic science of weights, paving the way for the physics of Galileo and Newton and seventeenth-century mechanistic ontologies. ${ }^{19}$

\section{From Economic Structures to Organic Intellectuals: the Gramscian Moment}

Working in the same years as Hessen and Grossman, the political leader and thinker Antonio Gramsci, who was a prisoner of the Fascist regime, reflected on epistemology, culture and the status of science in a direction that was specifically aimed at avoiding economic reductionism. His Quaderni del Carcere (Prison Notebooks) bear witness to his indirect knowledge of and interest in Grossman's approach to economy..$^{20}$ As far as science is specifically concerned, Gramsci built up his positions in direct and explicit opposition to Nikolai Bukharin's scientist

\footnotetext{
${ }^{17}$ Cf. Grossman in Freudenthal and McLaughlin (2009, 141).

18 On statics, cf. Renn and Damerow (2012). On turning objects, cf. Büttner (2008). On Ballistics, cf. Valleriani (2013). For studies in the history of mechanics making use of the concept of "challenging object," see Renn (2001) and Bertoloni Meli (2006).

${ }^{19}$ For a recent treatment of this trajectory, see Renn and Damerow (2010).

${ }^{20}$ Gramsci $(1975,890)$. The title of this section is inspired by one of the most updated introductions to Gramsci, Thomas (2009).
} 
Marxism. He accused the Soviet intellectual of vulgar materialism, rejected his assumption that the study of human society and history should be founded on positive science (historical materialism seen as Marxist sociology) and refused a monocausal and deterministic outlook on society. In order to reject Bukharin's positions, as expounded in Theory of Historical Materialism and in the intervention at the London congress of 1931, Gramsci offered a different reading of Marx's preface to the Kritik der politischen Ökonomie, one that emphasized the superstructural element. As one reads in his notes (Gramsci 1975, Notebook XI 64), "The issue of 'objectivity' of knowledge according to the philosophy of praxis [i.e. Marxism] can be developed beginning with the statement (entailed in the Critique of Political Economy) that 'men become conscious (of the conflict between material productive forces) in the ideological terrain' of juridical, political, religious, artistic and philosophical forms." 21 These words clearly show that Gramsci - who even undertook an Italian translation of Marx's preface in his translation notebooks (Gramsci 2007) - did not see the architectonic metaphor of Basis and Überbau as implying economic necessity and the unidirectional dependency of the ideological forms on the structure. ${ }^{22}$ Rather, he set the accent on Marx's observation, in the same preface, regarding the epistemological relevance of superstructures as the means by which people grasp and conceive of their positioning in the world. Thus, Gramsci pointed out the superstructural conditioning of science but added a significant specification: "One can say, however, that in the study of superstructures, science occupies a special place [un posto privilegiato], for its relation to the structure has a particular character, wider in extension and closer as far as the continuity of its development is concerned." 23

Gramsci resorted to another metaphor, a biological one, taken from the same pages of the Kritik der politischen Ökonomie in which the Basis-Überbau idea is introduced. Marx stated there that economy deals with the anatomy of society. ${ }^{24}$ Gramsci used the image of a living organism to translate the architectonic relation of structure and superstructure into the interdependency of skeleton and skin in a living body, in which the parts concur with the constitution of the whole (Gramsci 1975, Notebook X 41): "Structure and superstructure have a necessary and vital connection. [...] One cannot say that, in the human body, the skin and the type of physical beauty that prevails historically are mere illusions and that the skeleton and anatomy are the only reality, although something similar has been said for a long time. By enhancing the value of anatomy and the function of the skeleton nobody intended to assert that man, and even less so woman, can live without the latter." 25 Gramsci's perspective aimed

\footnotetext{
${ }^{21}$ Ibid., vol. 2, 1492 (my translation): "La questione della 'obiettività' della conoscenza secondo la filosofia della prassi può essere elaborata partendo dalla proposizione (contenuta nella prefazione alla Critica dell'economia politica) che 'gli uomini diventano consapevoli (del conflitto tra le forze materiali di produzione) nel terreno ideologico' delle forme giuridiche, politiche, religiose, artistiche, filosofiche."

${ }^{22}$ For an insightful treatment of diverging perspectives on structure and superstructure and their interconnection in Marxist thought, see Williams (1973).

${ }^{23}$ Gramsci (2007, 1457): "Si può dire, tuttavia, che nello studio delle superstrutture la scienza occupi un posto privilegiato, per il fatto che la sua relazione sulla struttura ha un carattere particolare, di maggiore estensione e continuità di sviluppo [...]."

${ }^{24} \operatorname{Marx}(1987,100)$ " [...] daß aber die Anatomie der bürgerlichen Gesellschaft in der politischen Ökonomie zu suchen sei."

${ }^{25}$ Gramsci (2007, 1321): "Tra struttura e superstruttura esiste un nesso necessario e vitale. [...] Nel corpo umano non si può certo dire che la pelle (e anche il tipo di bellezza fisica storicamente prevalente) siano mere illusioni e che lo scheletro e l'anatomia siano la sola realtà, tuttavia per molto tempo si è detto qualcosa di simile. Mettendo
} 
at undoing the allegations of "economicism" and "fatalistic mechanicism" often raised against Marxist thought. He took very seriously the historicist and idealistic objections raised by the philosopher Benedetto Croce, and partly accepted his criticism. Gramsci derived from Croce the idea that, complementary to economic analysis, a historical comprehension of society has to take into account culture, thought and hegemony, that is, intellectual and moral leadership and the construction of consensus, as essential elements of politics, besides domination and coercion. ${ }^{26}$

Such considerations motivated Gramsci's inquiries into the history of intellectuals in the thirteenth prison notebook. He stressed the social relevance of those intellectuals who embody the political aspirations of large social groups and are able to reinforce their interest by means of cultural and educational programs. Using a biological metaphor, Gramsci called them "organic intellectuals." Their realm of activity is civil society: They can be seen indeed as superstructural functionaries (Gramsci 1975, Notebook XIII 1, ibid., 1518-1519). Their action is as important as the government of political leaders and the economic activity of entrepreneurs, since culture is indispensable for the living body of human society. It should be remarked that organic intellectuals are not only lay people, as was the case with the public figure of the liberal philosopher Croce, but also exponents of the clergy. Gramsci did not neglect the hegemonic force of the Church in the organization and direction of society by means of education, culture and religion. Gramsci - who was sympathetic with Max Weber's inquiry into the ethical-religious side of capitalism - looked at Catholic institutions, such as the Jesuit Order, as historical examples of cultural hegemony. In such a perspective, the activity of a Renaissance Inquisitor such as the Jesuit Cardinal Robert Bellarmine proved much more effective in shaping modern Italy than the rather individualistic intellectual work of a "philosopher of immanence" like Giordano Bruno or a modern scientist like Galileo. ${ }^{27}$

Gramsci also addressed the delicate issue of the relation between politics, culture and religion. He especially reflected on the Jesuit cultural endeavor, which he treated from a cultural-political perspective as part of a wide struggle for hegemony in the field of ideas. In this light, he regarded a theological champion of the Counter-Reformation such as Bellarmine as an organic intellectual who effectively contributed to forge and develop a vision and project of social order. Not only was Bellarmine's epistemology embedded in a deeply political discourse, but his rehabilitation and his posthumous career as a Saint and as a Doctor of the Church was also part of a political project. This happened in particularly obscure years of European history. Bellarmine was in fact beatified in 1923, sanctified in 1931 and eventually elevated to the dignity of a Doctor of the Church in 1931. As Gramsci remarked in his Prison Notebooks, this apotheosis can be understood only against the background of the evolving relations between the Church and the State, of the expansion of the Jesuit influence within the Catholic Church and within society, and of the eventual collaboration between the Fascist State and the Vatican (Omodeo 2011). In those years, through the Patti lateranensi (Lateran Accords, 1929), Benito Mussolini obtained the support of Pius XI at the cost of a series of economic and civil concessions to the Church, including the teaching of religion in public

in valore l'anatomia e la funzione dello scheletro nessuno ha voluto affermare che l'uomo (e tanto meno la donna) possano vivere senza di essa." Also, see Notebook X, pt. 1, 12, note 5: vol. 2, 1237-1238.

${ }^{26}$ Gramsci (2007, vol. 2, 1211).

27 Cf. Omodeo (2011, 41-48). 
schools. These new political liaisons between Italy and the Catholic Church facilitated the transfer from Madrid to Rome of the editorial project of the Monumenta Historica Societatis Fesu, a vast operation aimed at presenting archival documents relative to the early years of the Jesuit Society to learned scholars and thus to induce a reappraisal of its history (Koch 1934). As for the reasons for Bellarmine's sanctification, they shall not be searched far from these events. According to the Jesuit Xavier-Marie Le Bachelet in the Dictionaire de théologie catholique (1932), the major theological merits of Bellarmine were genuinely "political" (Le Bachalet 1932). The significance of this strenuous opponent of the Reformation and of all heresies should not be restricted to his polemics against the Lutheran servum arbitrium. Rather, Bellarmine's doctrine included issues such as the affirmation of the primacy of the Roman pontiff, his indirect power over the worldly sphere, and the superiority of his divine monarchy over human civil powers. Gramsci's reflections on such a prominent early modern intellectual caution us against the pitfalls of studies on so-called "Jesuit science" if the political dimension is not taken into due account.

As important as it is in general terms, Gramsci's treatment of politics, culture and religion (and of intellectuals as cultural-political agents) does not include much discussion of scientists, that class of intellectuals of particular concern here. ${ }^{28}$ In the following, I will recount the most perceptive analyses about early modern scientists and then consider the perspectives that can be opened by integrating them within a cultural-political framework à la Gramsci.

From the viewpoint of the study of scientists as intellectuals, Edgar Zilsel's seminal work on the social context of science in the time of the Scientific Revolution is particularly relevant. In his best-known essay "The Sociological Roots of Science," which appeared in The American Fournal of Sociology in 1942, he investigated the origins of the figure of the modern scientist tracing his ${ }^{29}$ legacy back to three types of "knowledge bearers" corresponding to three "strata of intellectual activity:"30 university teaching, humanistic literacy and craftsmanship.

Zilsel's explanatory framework is economic: The rise of modern science is directly connected with the shift, in European history, from feudalism to capitalism, in the period between 1300 and 1600. He faced the question - similar to that famously investigated by the Marxist historian of science Joseph Needham in his monumental Science and Civilization in China (1954, $1^{\text {st }}$ volume) - of why modern science emerged at a certain point in space and time, that is, early modern Europe. Zilsel (who actually identified science and modern science) sought the answer in the socio-economic conditions of the rising capitalist society, in which urban classes of artisans and merchants augmented their power at the expense of the traditional aristocracy and clergy. Their material interests favored a worldly enterprise such as natural science, opposed to transcendent theology and aristocratic military art (i.e. the cultural fields of the ruling classes of feudalism). Bourgeois individualism produced a shift of values. It fueled competition and criticism at the expense of established authority. Criticism - Zilsel argued - is an ingredient of modern science. Moreover, a society emerged based on a rational division of labor. In it, technology and technological inventions had a recognizable economic value, unlike ancient societies, in which slave exploitation did not make the rationalization of labor

\footnotetext{
${ }^{28}$ Cf. Garin $(1958,1)$. "Gramsci risente di tutto un clima culturale [...] nella limitata attenzione rivolta [...] agli "scienziati." Also, see Geymonat, (1958, 148).

${ }^{29}$ It was only men in the period considered by Zilsel.

30 Both expressions stem from Zilsel. See Zilsel [1942] (2000).
} 
and the improvement of the means of production appear necessary. By contrast, in the age of early capitalism, technology (e.g. machinery) and rationalization (e.g. bookkeeping) became crucial and furthered the development of quantitative methods (Zilsel 2000, 936-938). At an intellectual level, technological advance, geographical discoveries, and economic transformation created a sense of superiority of modernity over tradition producing a profound crisis of both university scholasticism and humanism. At once, a new alliance between superior craftsmen and "respectable" scholars was established which constituted the necessary premise for the new science (Zilsel 1941, 27). Under these conditions a new type of intellectual emerged, as a sort of Gramscian "intellectual" concurrent with the rising bourgeoisie: the modern scientist, dealing with "worldly phenomena," endowed with a critical mindset, and interested in practical matters and technology.

The thesis of a causal dependency of science (in the singular) on the emergence of capitalism is also known in the history of science as the "Zilsel-Thesis." Particularly relevant to the discussion of the intellectuals involved in scientific advancement is what we could call a "corollary" of the Zilsel-Thesis: The societal transformations induced by economy made ageold prejudices and social barriers fall down, in particular the radical separation between free intellectual activity and manual labor. This permitted the new figure of the modern scientist to take shape, as somebody capable of connecting the experimental method of the lower craftsmen and the rational and systematic methods of upper-class elites, university-trained or humanistic: "On the whole, the rise of the methods of the manual workers to the ranks of academically trained scholars at the end of the sixteenth century is the decisive event in the genesis of science" (Freudenthal and McLaughlin 2009, 945). This merging of lower and higher cultures was no simple task. It was eased, in Zilsel's eyes, by the establishment of a class of superior craftsmen who occupied an intermediary rank between university scholars and the humanistic literati, above them, and the mass of "artisans, carpenters, shipbuilders, carpenters, foundrymen, and miners," beneath them. Superior craftsmen were acknowledged professionals: surgeons, makers of nautical, astronomical and musical instruments, surveyors, navigators and, most importantly for the history of mechanics, those whom Zilsel labeled the "artist-engineers." The latter category - which Zilsel freely derived from earlier scholarship, in particular from Leonardo Olschki - refers to the likes of Filippo Brunelleschi, Leonardo da Vinci, Leon Battista Alberti and Albrecht Dürer, people who "constructed lifting engines, canals and sluices, guns and fortresses [...] invented new pigments, detected the geometrical laws of perspective, and constructed new measuring tools for engineering and gunnery" (Freudenthal and McLaughlin 2009, 941). These were the "immediate predecessors" of the modern scientist.

The question arises: When did the modern scientist appear on the stage of history? Real science, as Zilsel stated, was born with Gilbert, Galileo and Francis Bacon. He extolled Gilbert's work on magnetism, De magnete (1600), as "the first printed book, written by an academically trained scholar and dealing with a topic of natural science, which is based almost entirely on actual observation and experiment." (Zilsel 1941, 1) Additionally, he observed that Gilbert's critical spirit was akin to that of radically anti-Aristotelian natural philosophers such as Bernardino Telesio, Tommaso Campanella, Giordano Bruno and Francesco Patrizi. However, Zilsel saw Renaissance naturalism as the "older brother, not the father" of experimental science. Gilbert's science stemmed from the practical knowledge of miners, 
foundrymen, navigators and instrument-makers (Zilsel 1941, 24). Thus, Zilsel regarded Gilbert as the first modern experimentalist.

The second prototype of the modern scientist, Bacon, who was seen by Zilsel as the champion of a science-oriented philosophy aiming at the control of nature and the advancement of learning for the common good. Bacon's technological utopia, Nova Atlantis (1627), inspired the founders of the first modern scientific societies in London and Paris (Zilsel 2000, 943-945). "Bacon, however, did not make any important discovery in the field of natural science, and his writings abound with humanistic rhetoric, scholastic survivals, and scientific mistakes." (Zilsel 2000, 944) From this viewpoint, Bacon did not "advance" much further than the aforementioned Italian naturalist philosophers.

Thirdly, Zilsel pointed to Galileo as the first intellectual capable of merging and harmonizing "craftsmen-like experimentation and measurement with learned mathematical analysis" (Zilsel 1941, 943). This is a reference to the two poles of Galilean epistemology, sensate esperienze and necessarie dimostrazioni. Zilsel believed that the different origin of the two constituents could be detected in Galileo's stylistic choices in the Discorsi e dimostrazioni matematiche intorno a due nuove scienze (Discourses and Mathematical Demonstrations Relating to Two New Sciences, 1638): Galileo presented the theorems in Latin, the language of erudition, and used Italian, the spoken language, for the discussion and assessment of the theories. This linguistic divide mirrored the social and epistemological separation that Galileo was successfully overcoming between the empiricism of the lower classes and the systematic reasoning of educated scholastics and humanists. What Zilsel neglected to mention, though, is that the elegant Italian spoken in the courts was not the same as the language of the folk. However, although this rectification might shed a different light on the persona of Galileo, who was a courtier rather than a popular, the idea of a double origin of his scientific method does not have to be abandoned.

It seems to me that two of Zilsel's insights are particularly fruitful when considering the history of science: first, his stress on the role of superior artisans and artist-engineers in the development of natural knowledge and mechanics; second, his identification of scholasticism and humanism as a rational-rhetoric culture that was at once rejected and absorbed by scientists and scientifically-minded philosophers of the seventeenth century.

The relationship between artists and early scientists has proved a precious heuristic hypothesis in studies on artisanal and practical knowledge, often connecting science and art history. ${ }^{31}$ In recent years, Pamela Smith has convincingly argued that the artistic/artisanal experience of the late Middle Ages and the Renaissance was an important constituent of early modern epistemology. Artistic production, seen as an activity capable of revealing the works of nature from inside, paved the way for experimental science; while naturalism in art corroborated the shift from a principle of authority, that is, the reliance on the scholarly tradition, to the observation of nature as the proper source of worldly knowledge (Smith 2004). As to the social necessity of "hybrid experts" capable of bringing together the technical and the theoretical dimensions of knowledge, their relevance would never diminish from the late Middle Ages to the Industrial Revolution and beyond. ${ }^{32}$ During the Renaissance, this

\footnotetext{
${ }^{31}$ On artisanal knowledge and its codification see Smith (2004) and Long (2001). On practical knowledge, see Valleriani (2017). On art and science in the Renaissance, one can look at, among others, Bredekamp (2002).

32 Ursula Klein has made this point most forcefully in Klein (2015).
} 
mediation was secured by a new group of intellectuals, already singled out by Zilsel, and later labeled as "scientist-engineers." Arguably, the most eminent among them was Galileo, the latecomer of a series of court mathematicians like his protector Del Monte and Benedetti. ${ }^{33} \mathrm{In}$ Galileo Engineer (2010), Matteo Valleriani has offered an accurate description of such scientistengineers. Galileo and his peers were well versed both in the technical and in the intellectual dimensions of knowledge. They underwent a period of apprenticeship of practical mathematics, in some field of application like architecture or the art of war, but later distanced themselves from artist-practitioners as they aspired to gain higher social recognition and prestige, especially at a court. They had a high degree of education as they mastered theoretical mathematics, the language of the learned, Latin, and the elegant literary Italian that was highly appreciated in the Renaissance courts. Scientist-engineers thus acted as mediators connecting the centers of power and decision, on the one side, and the workshops and building sites, on the other. As experts, they supervised artisanal work or gave advice on technical issues (Valleriani 2010, 208). As courtiers, they were additionally required to participate in the refined dialogical and literary culture of the elites, to serve as educators and to use their expertise to satisfy the curiosity of their rulers, for example, by casting horoscopes. I will come back to the sociopolitical issue of the courtly embedment of early modern scientists in Chapter 7.

A second important aspect highlighted by Zilsel relates to the institutional settings of knowledge: the towns of merchants and artisans, the universities of scholastic professors and the municipalities and courts of the humanists. In this respect it has to be remarked that university history has incredibly expanded as a field of inquiry in the last fifty years. Historians of science today tend to see education as crucial to the understanding of the reception, implementation, systematization and transfer of scientific theories. ${ }^{34} \mathrm{I}$ will limit myself to mentioning only a few significant contributions to our understanding of the role of institutions of higher education in shaping modern science. In his studies on Renaissance universities and in particular the Studio of Padua in Galileo's times, Charles Schmitt has stressed the centrality of university Aristotelianism as a model of rational strength, epistemological reflection and systematicity. The clearest example of scientific advance fostered by Aristotelian training is William Harvey's functional anatomy. His explanation of the heartbeat by means of a scholastic vis pulsiva proved superior to Descartes' mechanical substitution of such an "occult quality" for a chemical-hydraulic model of the circulation of blood. ${ }^{35}$ Further studies worth mentioning are those by Mordechai Feingold pointing to the decisive role played by English universities in the development of a mathematical culture in Newton's century and those by Antonella Romano on the teaching of mathematics at Jesuit colleges in France (Feingold 1984, Romano 1999). In the history of science, an interesting case is the dissemination of Copernican astronomy in the network of reformed universities gravitating around Wittenberg,

\footnotetext{
33 The figure of the "scientist engineer" was widely discussed in the history of science by Renn (2001), particularly in the contributions by Lefèvre (2001) and by Renn, Damerow and Rieger (2001). Valleriani discusses it in detail in Galileo Engineer (2010, chap. 6).

${ }^{34}$ For an assessment of the relevance of university history for the study of knowledge transfer, see my introductory chapter to Omodeo with Friedrich (2016, 3-21).

35 See Schmitt (1981). Regarding Descartes's views on the heartbeat see, among others, Grene (2005). As an insightful case study about the connection between mechanics and medicine in the seventeenth century via mechanicism, see Bertoloni Meli (2011).
} 
in spite of the aversion of the two leading figures of the Reformation, Martin Luther and Philipp Melanchthon, toward the heliocentric and geokinetic theory. ${ }^{36}$ This happened as a side effect of the reinforcement of the teaching of mathematics and astronomy for pedagogical and religious reasons - a heterogony of ends that Merton already pointed out with irony (Merton 1970 [1938]).

Regarding the connection of science with humanism, Zilsel rightly affirmed the importance of this cultural trend in the early modern period but his assessment was prejudiced by an exclusive consideration of the literary and rhetorical strands of humanism. Later scholarship has considered many instances of humanists devoted to mathematics and the natural sciences. ${ }^{37}$ One of the most significant was Federico Commandino whose contribution to the Archimedes Renaissance cannot be neglected in the history of mechanics. ${ }^{38}$ Arguably, new editions of classics from antiquity and the Middle Ages - including Latinized sources of Islamic origin - challenged modern readers, fueled debates and polemics, and disseminated intellectual tools that proved fundamental for the advance of science. The humanists Georg Peuerbach and Johannes Regiomontanus contributed to the restoration in Europe of Ptolemy's mathematical astronomy while Erasmus of Rotterdam disseminated the other Ptolemy by publishing the editio princeps of the Geography (1533). ${ }^{39}$ Among the innovators of cosmography, Copernicus and Amerigo Vespucci were both imbued with humanistic culture. ${ }^{40}$ To be sure, this list could be extended further.

Thus, in the light of more recent studies on institutions of higher education and humanism Zilsel's positions have to be integrated and revised; however, his suggestion to take them into account remains apt. Today, most historians of science agree upon the importance of scholasticism and humanism as cultural strands underlying early modern science alongside practical knowledge, but, unlike in the seminal debates of the first half of the twentieth century, a clarification of the general historical and epistemological coordinates that permits us to deal with the complex interdependency of science and sociocultural phenomena is often lacking. Hence, Zilsel's program - reflecting a more general Marxist program - of an interconnected understanding of the economic, institutional, and sociological settings, on the one hand, and the individuation of the cultural strands informing science, on the other, is still valuable.

Some limitations of Zilsel's perspective should be mentioned as well. First and most evidently, he conceived of science as a uniquely modern phenomenon. This identification highlights his marked Eurocentric perspective: "Fully developed science appears once only, in modern Western civilization" (Zilsel 2000, 396). In this respect, Hessen's approach was more nuanced. He investigated the early capitalist and social context of Newton's Principia without excluding that science has developed in the past, and can be furthered in the future, in different socioeconomic settings - to be sure, with different characteristics than Newton's science.

\footnotetext{
36 See, among many publications on the subject, Westman (1975).

37 The classic reference is Rose (1975), although the emphasis on humanism shows clear bias toward idealistic history and Eurocentrism.

38 See, among others, d'Alessandro and Napolitani (2013).

39 The best study on Peurbach and Regiomontanus is Zinner (1968), Engl. transl., Regiomontanus: His Life and Work (1990). On the wider humanistic context, also see Omodeo and Pasini (2014).

${ }^{40}$ On Copernicus' humanism, see Hallyn (2000), on Vespucci, Vogel (2006).
} 
Moreover, the priority Zilsel allotted to socio-economic factors and his predilection for the popular classes whom he saw as the main makers of modern experimental science produced blind spots in his historical analyses. Take his interpretation of Gilbert. As has been contended by critics, Zilsel's exclusive interest in Gilbert's experimental method made him neglect his participation in some of the most lively debates of his time, specifically, the insertion of his magnetic theory in the Copernican cosmological debates (Henry 2001). Notably, the controversy over the worldly or heavenly origin of early modern physics received an ideological connotation in the years of the Cold War. Just as Marxist scholars such as Zilsel emphasized experimentation, intellectual historians such as Koyré overemphasized the "Copernican Revolution" as the starting point of a process culminating with the Newtonian synthesis of terrestrial and celestial physics. ${ }^{41}$ Koyré exploited the proximity of astronomy to general views about the world and the divine since antiquity to argue for the spirituality of science and its speculative origins. ${ }^{42}$

The last point I would like to raise concerns the insufficient analysis of the cultural dimension of modern science, in particular its relation to politics, by early social historians of science such as Hessen and Zilsel. To be sure, Hessen stressed the ideological dimension of the theological conceptions permeating Newtonian science and rightly pointed to the political significance of religious positions, but he did not further this line of thought. Moreover, he generally denied a positive function to philosophical and theological conceptions in the advance of science. Instead, he saw them as either accessories or hindrances to scientific and social progress. Zilsel looked closer at the social and cultural settings of modern science. On the one hand, he indicated specific places and institutions (town, university, court); on the other hand, he specified the main intellectual strands (empiricism, scholasticism, humanism). He also named the different categories of knowledge bearers, namely the artist-engineer, the scholastic professor, and the humanist virtuoso who merged into the figure of the modern scientist. However, a comparison with Gramsci's "organic intellectuals" can show some limitations of Zilsel's concept of "knowledge bearers." While Zilsel's scientists and intellectuals are described in terms of the function descending from their position, Gramscian intellectuals are considered in relation to the action related to their identity. This difference helps to highlight what was excluded from Zilsel's consideration: the political dimension, that is, a reflection on agency and an understanding of institutional history in terms of hegemony and struggle. Both Hessen and Zilsel used arguments resting upon a rather simplistic treatment of culture, mechanically derived from class interests. My claim is that their lack of in-depth cultural and political analysis was a consequence of their philosophical premises. In Marxist terminology, they focused on the structural at the expenses of the superstructural or, in more plain terms, they almost exclusively treated the socio-economic aspects at the expense of the culturalpolitical.

This deficit was distinctly perceived by the scholars of the cultural turn of the late Eighties. As Steven Shapin and Simon Schaffer observed in a retrospective on their most

\footnotetext{
${ }^{41}$ Koyré (1961); Kuhn (1959); cf. Omodeo (2016b).

${ }^{42}$ Ernst Cassirer's understanding of the interconnection of astronomy and general worldviews in the Renaissance was led by a very different cultural agenda; his treatment was informed by the idea that the modern outlook coincided with a secularization of philosophy and of nature. See Cassirer (2002).
} 
influential work (speaking of themselves in the third person): "The authors of Leviathan and the Airpump [1985] were [...] dissatisfied with the 'extenalism-internalism debate' [...] The problems, they thought, lay with the identity and coherence of the categories themselves. One incoherence concerned the placement of the boundary between what was deemed internal and what external to science. On what grounds were social and political things accounted not 'intellectual'? And how was it that the making and warranting of scientific knowledge was judged not 'social'? Did other intellectual practices - say religion and magic - count as external (since they were not considered to be 'scientific')?" (Schaffer and Shapin 2011, XV) Leviathan and the Airpump sanctioned a historical approach that, since the Eighties, has devoted great attention to actors' perspectives, intentions and interactions: "Intellectual historians increasingly identified their goal as something like recreating past action in past actors' terms, and, from that point of view, the only pertinent categories and boundaries for interpreting past scientific action were said to be those recognized by those acting in the past." (Schaffer and Shapin 2011, XV) To be sure, the culturalization of science has opened up entirely new fields of research - for instance the investigation of astrology and alchemy as integral parts of the natural discourse of the Renaissance. Moreover, after the cultural turn, the exploration of cultural, philosophical, and religious themes informing upon science has become common. ${ }^{43}$ Topics such as the theological and ethical dimensions of science have increasingly attracted the attention of scholars interested in the ideological significance of the scientific debates of the past. $^{44}$

In spite of the positive fact that the field of inquiry has been expanded, I claim that this move has produced severe losses in our overall comprehension. It seems to me that the culturalist reaction to Cold-War externalism (based on the equation of externalism and Marxist economicism) often undergoes the opposite mistake when compared with economic reductionism. I would call it "culturalist relativism" (an epistemological category not to be confused with cultural relativism, pertaining to ethics). It mostly rests on shaky ground, due to insufficient clarification of the concept of culture and its relation to knowledge. It reinforces de facto the postmodern relativization and subjectivization of historical categories. Apart from epistemological difficulties - and this is not the place to expand on the philosophical definitions of culture from the viewpoint of historical epistemology 45 - the new trend in science studies has abandoned socio-economic considerations as ideologically flawed, thus throwing out the baby with the dirty bathwater. Explicit political concerns and engaged historiography have also become rare, as they have been substituted by "narratives."

In light of these developments, I claim that an integrated treatment of economy and politics is desirable, as it can avoid the Scylla of economic reductionism and the Charybdis of culturalist relativism. Since the opening up of such a third way is the problematic with which

\footnotetext{
${ }^{43}$ As an instance of culturalist revision (and revisionism) of earlier views about early modern science that emphasizes constituents such as religion, see Osler (2000).

${ }^{44}$ See for instance Steven Harris's treatment of "Jesuit spirituality" as a science-driving ideology in the context of early modern Jesuit engagement with scientific research and teaching, along a line of inquiry that has been opened up by Rivka Feldhay: Harris (1989).

${ }^{45}$ Let me stress the relevance of the philosophical discussions at the beginning of the twentieth century, ranging from neo-Kantianism and empiriocriticism to historical materialism, phenomenology and the philosophy of symbolic forms, as an extremely rich repository of perspectives and unfulfilled potentialities. On the divorce between science and philosophy in the turn of the Thirties, see Engler and Renn (2010). Moreover, for a critical assessment of the epistemological limitations of Cold-War philosophy of science, see Reisch, (2005).
} 
Gramsci specifically struggled, in particular in Notebooks X, the so-called Anti-Croce, and XI, the so-called Anti-Bukharin, I deem it useful to retake his insights and some of his crucial categories, in particular his emphasis on hegemony as a means to integrate the socialeconomic analysis with the cultural-political. For that purpose, it is necessary to readdress fundamental questions such as the interrelation of structures and identities and, on the basis of a theoretical translation of Gramscian categories, integrate the social with the political. ${ }^{46}$ Back in the Eighties, Stuart Hall saw Gramsci's philosophy of praxis as an alternative to structuralist approaches to cultural studies. Personally, I do not see the humanistic stress on agency, typical of Gramscian Marxism, as irreconcilable with structural analysis. As I have argued in this essay, it is rather the nesso vitale, the vital connection between socio-economic constraints and cultural-political action, that permits an integrated socio-political approach (Table 2). In science studies, such a perspective will permit investigation into both poles of intellectual history without incurring economic monocausal determinism, on the one hand, and the excesses of culturalist relativism, on the other. ${ }^{47}$

\section{References}

Anderson, Perry. 2016. The heirs of Gramsci. New Left Review 100: 71-97.

Badino, Massimiliano and Pietro D. Omodeo, ed. 2018. Cultural Hegemony in a Scientific World: Gramscian concepts for the history of science. Leiden: Brill.

Bertoloni Meli, Domenico. 2006. Thinking with objects: The transformation of mechanics in the seventeenth century. Baltimore: Johns Hopkins Univ. Press.

Bertoloni Meli, Domenitco. 2011. Mechanism, experiment, disease: Marcello Malpighi and seventeenthcentury anatomy. Baltimore: The Johns Hopkins University Press.

Bredekamp, Horst. 2002. Gazing hands and blind spots: Galileo as a draftman. In Galileo in context, ed. Jürgen Renn, 153-192. Cambridge: Cambridge University Press.

Bruskell-Evans, Heather. 2015. The hegemony of psychology. In Gramsci and Foucault: A reassessment, ed. David Kreps. Farnham-Burlington: Ashgate.

Büttner, Jochen. 2008. Big wheel keep on turning. Galilaeana 5: 33-62.

Bukharin, Nikolai. [1921] 1934. Historical materialism: A system of sociology. New York: International Publishers.

\footnotetext{
${ }^{46}$ Among the assessments on the vitality of Gramsci's thought today, especially see Anderson (2016). The presence and absence of Gramsci in science studies, in particular the concept of hegemony, is discussed in NietoGalan (2011), and Omodeo (2016a and 2016c). Nieto-Galan has particularly shown the usefulness of this appropriation for issues such as popularization and the circulation of knowledge in the public sphere: NietoGalan (2016). The theoretical reassessment of the Gramscian perspective, aimed at by this essay, is at the basis of the volume project edited by Badino and Omodeo (2018).

${ }^{47}$ In this respect, I deem post-structuralist readings of Gramsci, such as those of Ernesto Laclau and Chantal Mouffe, to sterilize rather than reinforce a crucial category such as that of hegemony by reducing it to identityconstitutive discursive struggles (Laclau and Mouffe 1985). By contrast, I would emphasize the fruitfulness of an approach to socio-cultural phenomena looking at the interrelation and tension between position and identity, as has been wonderfully done in the framework of Subaltern Studies. Gayatri Chakravorty Spivak, for one, has defined subalternity along a Gramscian line as "a position without identity" thus appropriating for subaltern studies a crucial issue of Marxist thought, traditionally addressed as the problem of the relation between class and consciousness. Cf. Spivak (2005, 476).
} 
Canguilhem, George. 2009. Qu'est-ce qu'une idéologie scientifique? In Canguilhem. Idéologie et rationalité dans l'histoire des sciences de la vie. Paris: Vrin, 39-55.

Cassirer, Ernst. [1927] 2002. Individuum und Kosmos in der Philosophie der Renaissance. Hamburg: Felix Meiner.

D'Alessandro, Paolo and Pier Daniele Napolitani. 2013 Archimedes in the $12^{\text {th }}$ and $16^{\text {th }}$ centuries. In Archimedes: The art and science of invention, ed. Giovanni Di Pasquale. Firenze: Giunti, 138-143.

Damerow, Peter, Gideon Freudenthal, Peter McLaughlin and Jürgen Renn. 2004. Exploring the limits of preclassical mechanics: A study of conceptual development in early modern science: Free fall and compounded motion in the work of Descartes, Galileo and Beeckman. Second edition. New York: Springer.

Engler, Fynn Ole and Jürgen Renn. 2010. Wissenschaftliche Philosophie, moderne Wissenschaft und historische Epistemologie. Albert Einstein, Ludwik Fleck und Moritz Schlick im Ringen um die wissenschaftliche Rationalität. Preprint 400. Berlin: Max Planck Institute for the History of Science, http://www.mpiwg-berlin.mpg.de/en/resources/preprints.

Feingold, Mordechai. 1984. The mathematicians' apprenticeship: science, universities and society in England 1560-1640. Cambridge: Cambridge University Press.

Freudenthal, Gideon and Peter McLaughlin. 2009. The social and economic roots of the Scientific Revolution. Texts by Boris Hessen and Henryk Grossmann. Dordrecht: Springer.

Garin, Eugenio.1958. Antonio Gramsci nella cultura italiana. In Studi gramsciani: Atti del convegno tenuto a Roma nei giorni 11-12 gennaio 1958. Rome: Editori Riuniti, 3-14.

Geymonat, Ludovico. 1958. Per un intervento al convegno di studi gramsciani. In Studi gramsciani: Atti del convegno tenuto a Roma nei giorni 11-12 gennaio 1958. Rome: Editori Riuniti, 147-148.

Gramsci, Antonio. 1975. Quaderni del carcere, ed. Valentino Gerratana. Turin: Einaudi.

Gramsci, Antonio. 2007. Quaderni di traduzioni (1929-1932), ed. Giuseppe Cospito. Rome: Istituto della Enciclopedia italiana, vol. 2, Notebook $7[\mathrm{a}]$.

Grene, Marjorie. 2005. Descartes and the heart beat: A conservative innovation. In Wrong for the right reason, ed. Jed Z. Buchwald and Allan Franklin. Dordrecht: Springer.

Grossman, Henryk. 2009. The Social Foundation of Mechanistic Philosophy and Menufacture. In The Social and Economic Roots of the Scientific Revolution. Texts by Boris Hessen and Henryk Grossmann, ed. Gideon Freudenthal and Peter McLaughlin. Dordrecht: Springer.

Habermas, Jürgen. 1969. Technik und Wissenschaft als 'Ideologie’. Frankfurt am Main: Suhrkamp.

Hall, Stuart. 1980. Cultural studies: two paradigms. Media, Culture and Society 2/1: 57-72.

Hallyn, Fernand. 2000. Copernic et Erasme. Humanistica Lovaniensia: Journal of Neo-Latin Studies 49: 89-100.

Harris, Steven J. 1989. Transposing the Merton thesis: Apostolic spirituality and the establishment of the Jesuit scientific tradition. Science in Context 3/1: 29-65.

Henry, John. 2001. Animism and empiricism: Copernican physics and the origins of William Gilbert's experimental method. Fournal of the History of Ideas 62/1: 99-119.

Klein, Ursula. 2015. Humboldts Preußen: Wissenschaft und Technik im Aufbruch. Darmstadt: Wissenschaftliche Buchgesellschaft. 
Koch, Ludwig. 1934. Jesuiten-Lexikon: Die Gesellschaft Jesu einst und jetzt. Paderborn: Bonifacius Druckerei.

Koyré, Alexandre. 1943. Galileo and Plato. Fournal of the History of Ideas 4: 400-428.

Koyré, Alexandre. 1961. La révolution astronomique: Copernic, Kepler, Borelli. Paris: Hermann.

Kuhn, Thomas S. 1959. The Copernican revolution: planetary astronomy in the development of western thought. New York: Random House.

Laclau, Ernesto and Chantal Mouffe. 1985. Hegemony and socialist strategy: towards a radical democratic politics. London: Verso.

Le Bachelet, Xavier-Marie J. 1932. Bellarmin. In Dictionnaire de théologie catholique. Paris: Letouzey.

Lefèvre, Wolfgang. 2001. Galileo engineer: art and modern science. In Galileo in context, ed. Jürgen Renn, 11-27. Cambridge: Cambridge University Press.

Long, Pamela O. 2011. Artisan/practitioners and the rise of the new sciences, 1400-1600. Corvallis: Oregon State University Press.

Marx, Karl. 1987. A contribution to the critique of political economy. In Karl Marx and Friedrich Engels, Collected works, vol. 29. London: Lawrence \& Wishart.

Merton, Robert K. 1938. Science, technology and society in seventeenth-century England. Osiris 4: 360-632.

Merton, Robert K. [1938] 1970. Science, technology and society in seventeenth century England. New York-Evanston-London: Harper Torchbooks.

Nieto-Galan, Augustí. 2011. Antonio Gramsci revisited: historians of science, intellectuals, and the struggle for hegemony. History of Science 49: 453-478.

Nieto-Galan, Augustí. 2016. Science in the public sphere: A history of lay knowledge and expertise. London-New York: Routledge.

Omodeo, Pietro D. 2011. Roberto Bellarmino: il grande inquisitor. In Il nostro Gramsci: Antonio Gramsci a colloquio con i protagonisti della storia d'Italia, ed. Angelo d'Orsi. Roma: Viella.

Omodeo, Pietro D. 2014. Copernicus in the cultural debates of the Renaissance: reception, legacy, transformation. Leiden: Brill.

Omodeo, Pietro D. 2015. The critical intellectual in the age of neoliberal hegemony: A discussion of Roger Cooter with Claudia Stein, Writing History in the Age of Biomedicine. Fournal for the Interdisciplinary History of Ideas 4/7: 5:1-5:20.

Omodeo, Pietro D. 2016a. After Nikolai Bukharin: history of science and cultural hegemony at the threshold of the Cold War era. History of Human Sciences 29 (4-5): 13-34.

Omodeo, Pietro D. 2016b. Copernicus as Kuhn's paradigm of paradigms: the epistemological dimension of The Copernican Revolution. In Shifting paradigms: Thomas S. Kuhn and the history of science, ed. Alexander Blum, Kostas Gavroglu, Christian Joas and Jürgen Renn.

Berlin: Edition Open Access, http://edition-openaccess.de/proceedings/8/7/index.html.

Omodeo, Pietro D. 2016c. Egemonia e scienza: Temi gramsciani in epistemologia e storia della scienza. Gramsciana: Rivista internazionale di studi su Antonio Gramsci 2: 57-84.

Omodeo, Pietro D. with Karin Friedrich. Duncan Liddel (1561-1613): Networks of Polymathy and the Northern European Renaissance. Leiden: Brill. 
Omodeo, Pietro D. and Enrico Pasini. 2014. Erasmian science: the influence of Erasmus of Rotterdam on early modern science, special issue of Journal of Interdisciplinary History of Ideas 6/2.

Osler, Margaret J. ed. 2000. Rethinking the Scientific Revolution. Cambridge: Cambridge University Press.

Porter, Roy. 1990. The history of science and the history of society. In Companion to the history of modern science, ed. Olby RG et al. London-New York: Routledge.

Reisch, George A. 2005. How the Cold War transformed philosophy of science. Cambridge: Cambridge University Press.

Renn, Jürgen ed. 2001. Galileo in context. Cambridge: Cambridge University Press.

Renn, Jürgen and Peter Damerow. 2007. Mentale Modelle als cognitive Instrumente der Transformation von technischem Wissen. In Übersetzung und Transformation, ed. Hartmut Böhme, Christoph Rapp and Wolfgang Rösler. Berlin: de Gruyter.

Renn, Jürgen, and Peter Damerow. 2010. The transformation of ancient mechanics into a mechanistic world view. In Transformationen antiker Wissenschaften, ed. Georg Toepfer and Hartmut Böhme. Berlin: de Gruyter.

Renn, Jürgen and Peter Damerow. 2012. The equilibrium controversy: Guidobaldo del Monte's critical notes on the mechanics of Jordanus and Benedetti and their historical and conceptual background.

Berlin: Edition Open Access, http://www.edition-opensources.org/sources/2/index.html.

Renn, Jürgen, Peter Damerow, and Simone Rieger. 2001. Hunting the white elephant: when and how did Galileo discover the law of fall? In Galileo in Context, ed. Jürgen Renn. Cambridge: Cambridge University Press: 29-149.

Romano, Antonella. 1999. La contre-réforme mathématique: Constitution et diffusion d'une culure mathématique jésuite à la Renaissance. Rome: École Française de Rome.

Rose, Paul L. 1975. The Italian Renaissance of mathematics: studies on humanists and mathematicians from Petrarch to Galileo. Geneva: Librairie Droz.

Schäfer, Lothar. 2012. Einleitung. In Ludwik Fleck, Entstehung und Entwicklung einer wissenschaftichen Tatsache: Einfiihrung in the Lehre vom Denkstil und Denkkollektiv. Frankfurt a.M.: Suhrkamp.

Schaffer, Simon and Steven Shapin. 2011. Leviathan and the air-pump: Hobbes, Boyle and experimental life. Princeton: Princeton University Press.

Schemmel, Matthias. 2008. The English Galileo: Thomas Harriot's work on motion as an example of preclassical mechanics. Dodrecht: Springer.

Schmitt, Charles. 1981. Towards a reassessment of Renaissance Aristotelianism. In Schmitt, Studies in Renaissance Philosophy and Science. London: Variorum Reprints.

Smith, Pamela. 2004. The body of the artisan: art and experience in the Scientific Revolution. Chicago: The University of Chicago Press.

Spivak, Gayari C. 2005. Scattered speculations of the subaltern and the popular. Subaltern Studies 8/4: 475-486.

Stachel, John. 1994. Marx's critical concept of science. Preprint 10. Berlin: Max Planck Institute for the History of Science.

Thomas, Peter 2009. The Gramscian moment: philosophy, hegemony and Marxism. Leiden-Boston: Brill. 
Valleriani, Matteo. 2010. Galileo engineer. Dordrecht: Springer.

Valleriani, Matteo. 2013. Metallurgy, ballistics and epistemic instruments: the Nova scientia of Nicolò Tartaglia. Berlin: Edition Open Access, http://www.edition-opensources.org/sources/6/index.html.

Valleriani, Matteo, ed. 2017. The structures of practical knowledge. Cham: Springer Nature.

Vogel, Klaus. 2006. Cosmography. In The Cambridge history of science, vol. 3., ed. Katharine Park and Lorraine Daston. Cambridge: Cambridge University Press.

Westman, Robert S. 1975. The Melanchthon circle, Rheticus and the Wittenberg interpretation of the Copernican theory. Isis 66: 163-193.

Williams, Raymond. 1973. Base and superstructure in Marxist cultural theory. New Left Review 82: 3-16.

Winkler, Rose-Luise. 2007. Ein unveröffentlichtes Manuskript von Boris M. Hessen: 'Materialien und Dokumente zur Geschichte der Physik.' Sitzungsberichte der LeibnizSozietät 92: 133-152.

Winkler, Rose-Luise. 2013. An den Urspüngen wissenschaftssoziologischen Denkens. Erstes Drittel des $X X$. Jahrhunderts (Russland/Sowjetunion). Berlin: trafo Wissenschaftsverlag.

Young, Robert M. 1990. Marxism and the history of science. In Companion to the history of modern science, ed. Olby RG et al. London-New York: Routledge, 23-31.

Zilsel, Edgar. 1941. The origins of William Gilbert's scientific method. Fournal for the History of Ideas 2/1: 1-32.

Zilsel, Edgar. [1942] 2000. The sociological roots of science. Social Studies of Science 30/6: 935939.

Zinner, Ernst. [1968] 1990. Leben und Wirken des Foh. Müller von Königsberg genannt Regiomontanus, Engl. transl., Regiomontanus: His Life and Work. Amsterdam: North-Holland. 